\title{
Environmental and biological monitoring of exposure to ethylenebisdithiocarbamate fungicides and ethylenethiourea
}

\author{
P Kurttio, $T$ Vartiainen, $K$ Savolainen
}

\begin{abstract}
Exposure of workers to ethylenebisdithiocarbamates (EBDCs; maneb or mancozeb) in 29 potato farms was evaluated during the control of potato late blight. Concentrations of EBDCs and ethylenethiourea (ETU), an impurity and degradation product in EBDC formulations, in ambient air were evaluated during pesticide application. Biological monitoring of exposure to EBDCs was carried out by measuring the concentrations of ETU, a metabolite of EBDCs, in urine for 22 days after the end of the exposure. The estimated inhaled doses of ETU and EBDCs during the average four hour application period were 0.07 and $1.8 \mu \mathrm{g} / \mathrm{kg}$, respectively. Only $1-10 \%$ of ETU on the clothes reached the skin. The creatinine corrected concentrations of ETU in urine were $0 \cdot 1-2 \cdot 5 \mu \mathrm{g} / \mathrm{mmol}$ creatinine 24 hours after exposure ended. The estimated half life for eliminating ETU through the kidneys was close to 100 hours. These results indicate that the measurement of ETU in urine is suitable for biological monitoring of exposure to EBDCs.
\end{abstract}

Ethylenebisdithiocarbamates (EBDCs) are widely used fungicides in agriculture and forestry. Ethylenethiourea (ETU), a degradation and a byproduct of the manufacturing of EBDCs, is formed during their storage. ${ }^{1}$ Moreover, EBDCs are metabolised by mammals to ETU..$^{2-6}$ Even though the acute toxicity of pure EBDCs is low, the health of workers may be jeopardised by inhaling ETU or EBDCs. ${ }^{7}$

ETU causes thyroid hyperplasia and pronounced alterations in the levels of thyroid hormones in serum $^{8}$ and is also known for its remarkable teratogenic potency. ${ }^{9}$ ETU may be genotoxic ${ }^{1011}$ and carcinogenic in experimental animals. ${ }^{1213}$ The National Institute of Occupational Safety and Health

Department of Environmental Hygiene and Toxicology, National Public Health Institute, SF70701 Kuopio, Finland

P Kurttio, T Vartiainen, K Savolainen considers ETU a potential human carcinogen. ${ }^{14}$

In several studies EBDCs and ETU have been strong skin sensitisers ${ }^{15-21}$ even though controversial reports exist. ${ }^{20}$ Also, temporary alterations in central nervous functions, ${ }^{23}$ diarrhoea, and acute renal and transient heart failure ${ }^{24}$ have been reported after exposure to EBDCs. In these cases the exposure conditions have, however, not been fully described. In terms of exposure, however, EBDCs and ETU may be absorbed through the lungs, gastrointestinal tract, and skin. ${ }^{25}$ Thus there is a strong need to develop suitable methods for biologically monitoring exposure to these compounds.

In the present study the concentration of ETU in pesticide formulations and ambient air were measured and exposure to EBDCs was evaluated; contamination of clothes and skin was also measured. Workers were biologically monitored for exposure to EBDCs and ETU by measuring ETU in urine after the end of the exposure.

\section{Subjects and methods}

SUBJECTS AND APPLICATION OF THE PESTICIDE

Exposure of pesticide operators to EBDC fungicides was studied in 29 potato farms during the summer of 1987. Potato fields were sprayed with EBDC formulations to control potato late blight. There was always several weeks between the sprayings so that each worker was always studied after a single exposure. A tractor pulled pump operated spray equipped with a 300-500 1 tank was used. Pressure during the spraying operation was $2-4 \mathrm{kp} /$ $\mathrm{cm}^{2}$. The height of the nozzles was about $50 \mathrm{~cm}$ above the ground. The mean area of a sprayed field was 14 $(\mathrm{SD} \pm 9) \mathrm{ha}$. Spraying time was $0 \cdot 5-7 \mathrm{~h}$ (mean $4 \mathrm{~h}$ ).

\section{PREPARATIONS}

Powdered Maneba ( $80 \%$ maneb) or Ridomil ( $56 \%$ mancozeb) was used. Before each application, the powder was poured into a tank that was then filled with cold water. The concentrations of pesticide formulation within the solutions were $5-12 \mathrm{~g} / \mathrm{l}$. The mean concentrations of the effective ingredients, maneb or mancozeb, in the solution were 4 or $7 \mathrm{~g} / \mathrm{l}$, respectively. Ambient air sampling was always conducted for the whole application period. 
SAMPLING

Air samples were collected from 14 potato farmers. Samples in the breathing zone of the farmers and in the cabin of the tractors used were collected on membrane filters $(0.8 \mu \mathrm{m}$, Millipore $)$ using a portable pump (MSA Model S) with a flow of $2-31 / \mathrm{min}$. Sampling times were equivalent to application times (range $0.5-7 \mathrm{~h}$ a day; mean $4 \mathrm{~h}$ ). Air samples during the weighing and mixing of the pesticide with water (5-15 min) were collected with a Resiprotor pump $(201 / \mathrm{min})$.

Contamination of clothes and skin was evaluated with patch samples attached to the clothes and skin with a tape (effective filter paper area $10 \times 10 \mathrm{~cm}$ ). Filter papers (Whatman) were placed on the back, chest, thigh, and forearm on the clothes and in corresponding places on the skin (fig 1). The filter papers were kept in place for the whole application time. Also, all EBDC formulations were analysed for concentrations of ETU. The samples were stored at $+4^{\circ} \mathrm{C}$ until analysed.

A 24 hour urine sample was collected from each of the 29 potato field operators immediately after the end of the exposure and thereafter at a seven day interval for three weeks (days 1, 8, 15, and 22).

\section{ANALYSIS OF ETU}

The analysis of ETU on filter papers and in urine samples was carried out as described earlier. ${ }^{26}$ Briefly, a membrane filter and $2 \mathrm{ml}$ of distilled water were added into a $50 \mathrm{ml}$ decanter or a filter paper (= patch sample) and $6 \mathrm{ml}$ of water were added into a $20 \mathrm{ml}$ test tube. The samples were kept in a sonicating water bath for 60 minutes without heating and mixed for 20 minutes in a mechanical shaker. The samples were filtered before the analysis.

To analyse the amount of ETU impurity in the formulations, a known amount of the EBDC for-

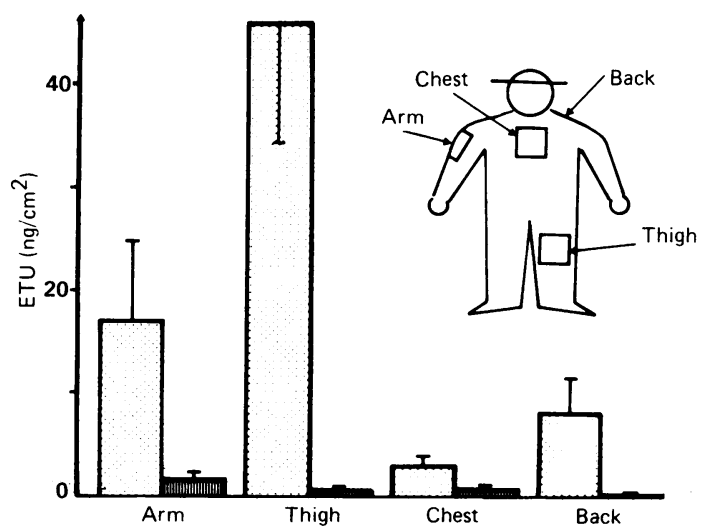

Fig 1 Ethylenethiourea (ETU) concentrations on back, chest, thigh and forearm on clothes (light bars) and on corresponding areas of skin (dark bars) during weighing, mixing, and application of EBDC fungicides. mulation was weighted to a $50 \mathrm{ml}$ measuring flask and diluted with distilled water. The concentration of ETU in the sample was then analysed as described earlier. ${ }^{26}$

To measure ETU in urine, $10 \mathrm{ml}$ of a 24 hour urine sample was evaporated to dryness in a rotavapor. Thereafter, methanol $(2 \mathrm{ml})$ and silica gel $(150 \mathrm{mg})$ were added. After the methanol evaporated the sample was transferred on to a methanol washed aluminium oxide column and eluted with $20 \mathrm{ml}$ of $2 \%$ methanol in dichloromethane. The eluate was evaporated to dryness and the sample was dissolved in $0.5 \mathrm{ml}$ of water and filtered.

High pressure liquid chromatographic analysis of ETU in different samples was carried out using a Hewlett Packard 1090 liquid chromatograph equipped with a diode array detector (Hewlett Packard, Palo Alto, USA). The column was a reverse phase Hypersil 5 ODS $\left(25 \mathrm{~cm}, \frac{1}{4} " \times 4.6 \mathrm{~mm}\right.$, Chrompack, Holland) kept in an oven at $40^{\circ} \mathrm{C}$. The isocratic elution of $5 \%$ methanol in $0.05 \mathrm{M}$ ammonium acetate in water was used. The detection wavelength was $230 \mathrm{~nm}$.

Creatinine concentrations of urine samples were determined with a routine clinical method.

\section{ANALYSIS OF RESULTS}

Mean and standard error of mean were calculated for ETU concentrations in air and on filters. Median and range are given for the creatinine corrected ETU concentrations in urine. The elimination half life of ETU in urine was evaluated using a graphic method.

\section{Results}

ETU IN AIR

The overall range of concentrations of ETU in air were between 0.004 and $3.3 \mu \mathrm{g} / \mathrm{m}^{3}$ in the breathing zone and 0.006 and $0.8 \mu \mathrm{m}^{3}$ in the tractor cabin (fig 2).

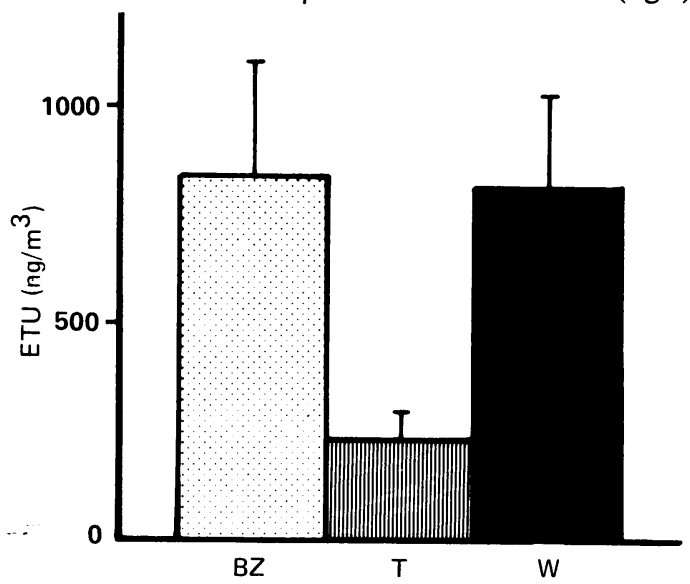

Fig 2 Ethylenethiourea concentrations in breathing zone $(B Z)$, tractor cabin $(T)$, and during weighing and mixing of EBDC pesticides (W). Concentration of ETU in ambient air is given as $\mathrm{ng} / \mathrm{m}^{3}$. Mean and SEM are given. 
The sample during weighing or mixing of the pesticide was collected for 10 minutes (range 5-15 minutes). Because of the short sampling time, the concentrations of ETU in the breathing zone were between the limit of the detection of the method, $8 \mathrm{ng} /$ filter, and $2.0 \mu \mathrm{g} / \mathrm{m}^{3}$. For maneb and mancozeb containing formulations the mean concentrations of all measurements of ETU in air were 0.5 and $0.8 \mu \mathrm{g} /$ $\mathrm{m}^{3}$, respectively. The mean concentrations of ETU in maneb $(80 \%)$ and mancozeb $(56 \%)$ containing formulations were 59 and $22 \mathrm{mg} / \mathrm{g}$, respectively. Based on these numbers the mean calculated concentrations of active maneb and mancozeb in air were 7 and $20 \mu \mathrm{g} / \mathrm{m}^{3}$, respectively.

\section{ESTIMATED EXPOSURE TO EBDCS}

The estimated average exposure of an operator to EBDCs through the lungs was calculated as follows. The average concentration of ETU in the breathing zone was $843 \mathrm{ng} / \mathrm{m}^{3}$. The mean concentration of ETU in various EBDC formulations was $41 \mu \mathrm{g} / \mathrm{g}$ active EBDC ingredient. Thus the average concentration of EBDC pesticide in the air was $21 \mu \mathrm{g} / \mathrm{m}^{3}$.

The assumed mean ventilation during the average mean four hour application period was $25 \mathrm{l} / \mathrm{min}$ corresponding to a light or moderate workload. ${ }^{27}$ The average body weight (bw) of the applicators was 70 kg. These estimations resulted in the total inhaled amount of ETU and EBDCs of 5 and $126 \mu \mathrm{g} /$ day, respectively. This corresponds to a dose of $0.07 \mu \mathrm{g}$ of $\mathrm{ETU} / \mathrm{kg}$ bw and $1.8 \mu \mathrm{g}$ of EBDC/kg bw. Acceptable daily intake values for consumers of ETU is $2 \mu \mathrm{g} / \mathrm{kg}$ bw and of EBDCs $500 \mu \mathrm{g} / \mathrm{kg}$ bw. Thus these estimated occupational exposures are only $3.5 \%$ and $0.4 \%$ of the acceptable daily intake values for ETU and EBDCs, respectively. ${ }^{28}$

\section{ETU ON SKIN AND CLOTHES}

Protective clothing effectively prevented large amounts of ETU or EBDCs from reaching the skin (fig 1). The contamination rates for ETU on the clothing on the back, chest, shoulders, and forearms were $5,2,9$, and $14 \mathrm{ng} / \mathrm{cm}^{2}$ an hour. The contamination rates in the corresponding areas of the skin were $0.07,0.19,0.39$, and $0.17 \mathrm{ng} / \mathrm{cm}^{2}$ an hour. Therefore only $1.4 \%, 10 \%, 4 \%$, and $1.2 \%$ of ETU that contaminated the clothes reached the skin during the exposure in the back, chest, shoulders, and forearms, respectively. The limit of detection for ETU on the clothes or the skin was $24 \mathrm{ng} /$ filter paper.

\section{ETU IN URINE}

The concentrations of ETU in 24 hour urine samples were $0.09-2.5$ (day 1 ), $0.07-1.0$ (day 8), $0.01-0.3$ (day 15 ), and $<0.01-0.2 \mu \mathrm{g} / \mathrm{mmol}$ creatinine (day 22 ), respectively, after exposure ended (fig 3 ). As a whole, the absolute concentrations of ETU in all samples were between $<0.2$ and $11.8 \mu \mathrm{g} / \mathrm{l}$ of urine. Based on a

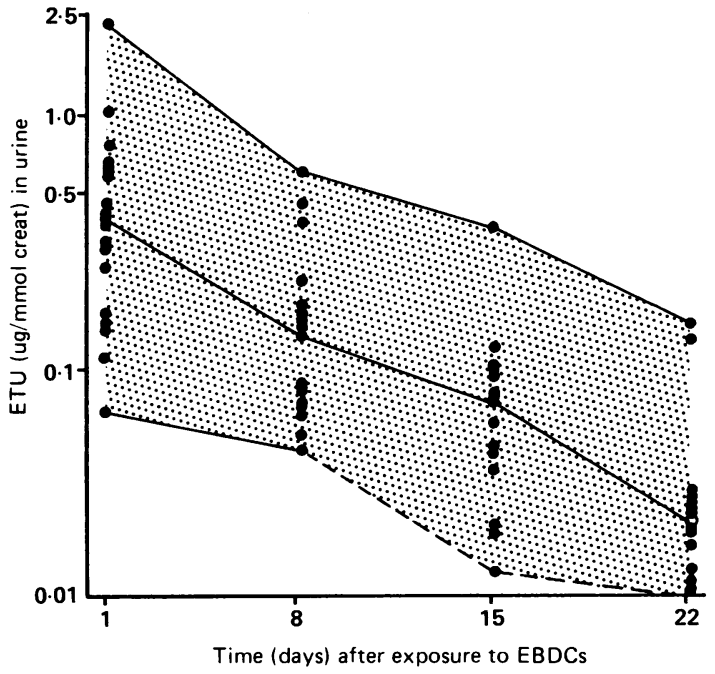

Fig 3 Excretion of ethylenethiourea (ETU) in urine of potato farmers after exposure to ethylenebisdithiocarbamates (maneb or mancozeb). Results are presented as semilogarithmic plot for determining elimination half life of ETU in urine. Median, range, and each determination are shown for each time point. Dotted line is used when lowest ETU concentrations in urine were too low for quantitative determination.

graphic method, the urinary elimination half life for ETU was, under these exposure conditions, about 100 hours (fig 3). This long half life emphasises the long exposure period (mean $4 \mathrm{~h}$, range $0.5-7 \mathrm{~h}$ ) and possibly an important contribution of slow dermal penetration of ETU and EBDCs during and after exposure ended. Also, only the slow elimination phase of ETU could be estimated because the sampling strategy did not allow the estimation of the elimination of ETU during the absorption or distribution of EBDCs and ETU.

\section{Discussion}

Exposure to ETU and the calculated exposure to EBDCs was greatest by ambient air; exposure in the well protected tractor cabin was insignificant. Clothing was important in protecting against exposure. Under the present exposure conditions the elimination of ETU in urine was slow. The new method of detecting ETU was useful for the estimation of low occupational exposure to ETU and EBDCs.

Only $1-10 \%$ of ETU on clothes reached the skin which emphasises the importance of protective clothing. Also, the concentrations of ETU and EBDCs in the tractor cabins were lower than under other exposure conditions. Exposure to EBDC and ETU powders and aerosols through the lungs was most significant but it can probably be appreciably prevented by respiratory masks.

Concentrations of ETU in occupational air have 
not been reported earlier. Nilsson et al collected samples from the breathing zone of nursery workers exposed to mancozeb and found concentrations of $<0.02 \mathrm{mg} / \mathrm{m}^{3}{ }^{29}$ The present mean concentration of ETU in the breathing zone of a comparable group of workers using maneb was $0.007 \mu \mathrm{g} / \mathrm{m}^{3}$ (data not shown). This corresponds to an exposure of about $0 \cdot 2$ $\mu \mathrm{g} / \mathrm{m}^{3}$ of maneb. Nilsson $e t$ al also found that levels of mancozeb in air during the mixing and filling of the spraying tank was $0.2 \mathrm{mg} / \mathrm{m}^{3} .{ }^{30}$ The present ETU and estimated EBDC concentrations were $0.9 \mu \mathrm{g}$ and 0.02 $\mathrm{mg} / \mathrm{m}^{3}$, the estimated EBDC concentrations being only $10 \%$ of those reported earlier. This may be due to different working methods.

There are no widely accepted threshold limit values (TLV) for EBDC fungicides but a TLV of 5 $\mathrm{mg} / \mathrm{m}^{3}$ for thiram has been applied for various EBDCs. ${ }^{31}$ In agreement with earlier findings the present exposure to EBDCs was clearly below the applied TLV values. ${ }^{30}$ Maini and Boni have reported concentrations of EBDCs during the production of EBDCs indoors a hundred times higher ${ }^{31}$ than the highest reported concentrations in agriculture outdoors. ${ }^{30}$ The exposure to EBDCs or ETU reported here did not exceed the acceptable daily intake values recommended by the Food and Agriculture Organisation for an average consumer for a lifetime. ${ }^{28}$

The wide range of ETU concentrations in urine indicate that the exposure of workers differs considerably between individuals. The reason for this may be application time, different working habits, experience, personal hygiene, and protective clothing. The elimination half life-close to 100 hours-of ETU in urine after the end of exposure to EBDCs and to their ETU impurity was surprisingly long. Contributing factors may be the continuation of the actual exposure after the end of the application. In fact, absorption of EBDCs and ETU through the skin and the gastrointestinal tract may have an impact on the excretion of absorbed ETU and of EBDCs as ETU. Also, pesticides were usually stored in places where frequently used farming equipment was stored. Thus occasional exposure in addition to the application periods may have taken place. Based on exposure estimations, probably most of the ETU in urine originates from absorbed EBDCs rather than ETU impurity in EBDC formulations.

We thank Ms Teija Korhonen and Ms Pirkko Mustonen for skillful technical help. This study was financially aided by the Finnish Work Environment Fund.

1 Engst R, Schnaak W. Residue of dithiocarbamate fungicides and metabolites on plant foods. Residue Rev 1974;52:45-67.

2 Newsome WH. The excretion of ethylenethiourea by rat and guinea pig. Bull Environ Contam Toxicol 1974;11:174-6.
3 Kato Y, Odanaka Y, Teramoto S, Matano O. Metabolic fate of ethylenethiourea in pregnant rats. Bull Environ Contam Toxicol 1976;16:546-55.

4 Jordan LW, Neal RA. Examination of the in vivo metabolism of maneb and zineb to ethylenethiourea (ETU) in mice. Bull Environ Contam Toxicol 1979;22:271-7.

5 Brocker ER, Schlatter C. Dose dependence of the excretion of maneb metabolites in urine of rats. Toxicol Lett 1980;6:221-4.

6 Camoni I, Cicero AM, Di Muccio A, Dommarco R. Measurement of urinary excretion of ethylenethiourea (ETU) in zineb-treated rats. Med Lav 1984;75:207-14.

7 Fishbein L. Environmental health aspects of fungicides. I. Dithiocarbamates. J Toxicol Environ Health 1976;1:713-35.

8 Kurttio P, Savolainen K, Tuominen R, et al. Ethylenethiourea and nabam induced alterations of function and morphology of thyroid gland in rats. Arch Toxicol 1986;9:339-44S.

9 Khera KS. Ethylenethiourea-induced hindpaw deformities in mice and effects of metabolic modifiers on their occurrence. $J$ Toxicol Environ Health 1984;13:747-56.

10 Seiler JP. Ethylenethiourea (ETU), a carcinogenic and mutagenic metabolite of ethylenebisdithiocarbamate. Mutat Res 1974;26:189-91.

11 Klopman G, Contreras R, Rosenkratz HS, Waters MD. Structure-genotoxic activity relationships of pesticides: comparison of the results from several short-term assays. Mutat Res 1985;147:343-56.

12 Innes JRM, Ulland BM, Valerio MG, et al. Bioassay of pesticides and industrial chemicals for tumorigenicity in mice. J Natl Cancer Inst 1969;42:1101-14.

13 Andrianova MM, Alekseev IV. Carcinogenic properties of the pesticides sevin, maneb, ziram and zineb. Vopr Pitan 1970;29:71-4.

14 Stein HP, Bahlman LJ, Leidel NA, Parker JC, Thomas AW, Millar JD. Ethylenethiourea (ETU). Am Ind Hyg Assoc J 1978;39:A34-8.

15 Burry JN. Contact dermatitis from agricultural fungicide in South Australia. Contact Dermatitis 1976;2:289.

16 Nater JP, Terpstra H, Bleuminik E. Allergic contact sensitization to the fungicide maneb. Contact Dermatitis 1979;5:24-6.

17 Kleibl K, Ràc'kovà $M$. Cutaneous allergic reactions to dithiocarbamate. Contact Dermatitis 1980;6:348-9.

18 Adams RM, Manchester RD. Allergic contact dermatitis to maneb in a housewife. Contact Dermatitis 1982;8:271.

19 Bruze M, Fregert S. Allergic contact dermatitis from ethylenethiourea. Contact Dermatitis 1983;9:208-12.

20 van Ketel WG, van den Berg WHHW. The problem of the sensitization to dithiocarbamates in thiuram-allergic patients. Dermatologica 1984;169:70-5.

21 Lisi P, Caraffini S. Pellagroid dermatitis from mancozeb with vitiligo. Contact Dermatitis 1985;13:124-5.

22 Rudzki E, Ostaszewski K, Grzywa Z, Kozlowska A. Sensitivity to some rubber additives. Contact Dermatitis 1976;2:24-7.

23 Israeli $R$, Sculsky $M$, Tiberin $P$. Acute intoxication due to exposure to maneb and zineb. A case with behavioural and central nervous system changes. Scand $J$ Work Environ Health 1983;9:47-51.

24 Koizumi A, Shioujima S, Omiya M. Acute renal failure and maneb (mangane ethylenebis(dithiocarbamate)) exposure. JAMA 1979;242:2583-5.

25 Plunkett ER. Handbook of industrial toxicology. (25.) New York: Chemical Publishing Co, Inc, 1976:157.

26 Kurttio P, Vartiainen T, Savolainen K. A high pressure liquid chromatographic method for the determination of ethylenethiourea in urine and on filters. Anal Chim Acta 1988;212 297-301.

27 Engst R, Schnaak W. Residue of dithiocarbamate fungicides and metabolites on plant foods. Residue Rev 1974;52:45-67.

28 Food and Agriculture Organisation. Pesticide residues in food 1980: dithiocarbamate fungicides. Rome: FAO, 1981:180-94.

29 Nilsson C-A, Eriksson K, Kragh E, Nygren O. Exponering för damm och mancozeb vid upptagning av tallplantor. Untersökingsrapport 1986:37 Arbetarskyddsstyrelsen, forskningsavdelningen, Umeå.

30 Nilsson C-A, Nygren O, Sikström E. Determination of mancozeb in air. Occupational exposure during its use in control of potato late blight. Chemosphere 1987;16:2423-8.

31 Maini P, Boni R. Gas chromatographic determination of dithiocarbamate fungicides in workroom air. Bull Environ Contam Toxicol 1986;37:931-7.

Accepted 5 May 1989 